\title{
An Innovative Information System for College Management
}

\author{
Chaitra B. S. \\ College of Computer \& Information Science, Srinivas University, Mangalore, India \\ E-mail: geminichaitra@gmail.com
}

Type of the Paper: Research Paper.

Type of Review: Peer Reviewed.

Indexed in: OpenAIRE.

DOI: http://doi.org/10.5281/zenodo.1297442.

Google Scholar Citation: IJMTS

\section{How to Cite this Paper:}

Chaitra B. S. (2018). An Innovative Information System for College Management. International Journal of Management, Technology, and Social Sciences (IJMTS), 3(1), 140145. DOI: http://doi.org/10.5281/zenodo.1297442.

International Journal of Management, Technology, and Social Sciences (IJMTS) A Refereed International Journal of Srinivas University, India.

(C) With Author.

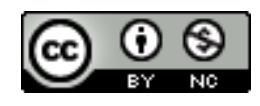

This work is licensed under a Creative Commons Attribution-Non Commercial 4.0 International License subject to proper citation to the publication source of the work.

Disclaimer: The scholarly papers as reviewed and published by the Srinivas Publications (S.P.), India are the views and opinions of their respective authors and are not the views or opinions of the SP. The SP disclaims of any harm or loss caused due to the published content to any party. 


\title{
An Innovative Information System for College Management
}

\author{
Chaitra B. S. \\ College of Computer \& Information Science, Srinivas University, Mangalore, India \\ E-mail: geminichaitra@gmail.com
}

\begin{abstract}
This is an information system application called Electronic-College Management and Information System (ECMIS) which is useful for staff, faculty, and principal to deal with all information about student details, academic related reports, college details, course details, batch details and other related details. This is user friendly and easy to use system. All the important data are stored in the database and it avoids any miscalculation. It replaces the old and traditional file (paperwork) storing process; it even provides editing facilities for data which would be tedious through paperwork. It eliminates manual work (Manual system does not mean that we are working with pen and paper, it also includes working on spreadsheets and other simple software's). With this we can retrieve student's information instantly. The major benefit of this web portal is to store the student's information in one place and can be accessed easily. This is a software application which is responsive in nature.
\end{abstract}

Keywords: User friendly, Responsive, Miscalculation, Database.

\section{INTRODUCTION :}

This software application is useful in handling all details about a student. The details include subject details, student personal details, academic details; attendance details etc. It even allows the staff and faculty to view attendance shortage details. Staffs can search and update the data systematically [1]. It will give information about different events that will be conducted by college time to time, as well as providing details about college holidays. Information about these will be updated. Students can view their exam performances and attendance status and even access study materials according to their requirement that are being uploaded by the faculty. They can even update their current aggregate marks to check their eligibility for various Recruitment opportunities. This system is aimed at developing an E-College Management and Information System (ECMIS) that is of importance to either an educational institution or a college. The main motive of the project is to provide full automation to the user.

\section{OBJECTIVE :}

This is a web oriented application which allows staff, faculty, and principal to deal with whole information about student details, academic related reports, college details, course details, batch details and other related details [2]. College Staff are able to directly access all aspects of a student's academic progress through a secure, online interface embedded in the college website [3]. It is a mandatory process in the educational system which directly reflects the student progress. In educational institutes, attendance management is normally a manual process. It tracks all the details of a student from the day one to the end of his course which can be used for all reporting purpose, tracking of marks, fees details etc. It even allows the faculty to upload study materials which can be accessed by students easily, and all these will be available for future references. It even provides information about College Holidays, Special Events, Ranks, and Placements. Different reports and Queries can be generated based on options related to students, batch, course, staff, and faculty. The system is user friendly and easy to use. This system is an online web based system which implements a 
user friendly and attractive interface for college [4]. College management module like attendance management, student/staff information management is important in college level enterprise management [5]. This system replaces the current paper records into automated form [6].

\section{TECHNOLOGY USED :}

This system is developed using various technologies such as PHP (Php Hyper Text Preprocessor), CSS (Cascading Style Sheet), HTML (Hyper Text Mark-up Language), JavaScript which are been used at the Front-end and at the Back-end MySQL is been used which is used to store and access information efficiently. This system has also used Bootstrap which is used to increase the responsiveness [7] - which helps to view the applications on varying screen sizes.

\section{FUNCTIONAL REQUIREMENTS :}

This system aims to improve the efficiency of college information management, and the main function is managing and maintaining information [8]. The administrator and students are two major functional requirements in the system. The Administrator will be given more powers (enable/disable/ update) than other users. It will be ensured that the information entered is of the correct format. For example name cannot contain numbers. In case if incorrect form of information is added, the user will be asked to fill the information again. Students use the system to query and enter their information only.

\section{NON-FUNCTIONAL REQUIREMENTS :}

\section{- Performance Requirements:}

The proposed system that we are going to develop will be used as the chief performance system for helping the organization in managing the whole database of the student studying in the organization. Therefore, it is expected that the data base would perform functionally all the requirements that are specified.

- Safety Requirements:

The database may get crashed at any certain time due to virus or operating system failure. Therefore, it is required to take the database backup [9].

\section{WORKING PRINCIPLES :}

E-college Management and Information system" operates and provides facilities, mainly based on the following modules:

- Faculty Module

- Staff Module

- Student Module

- Principal Module

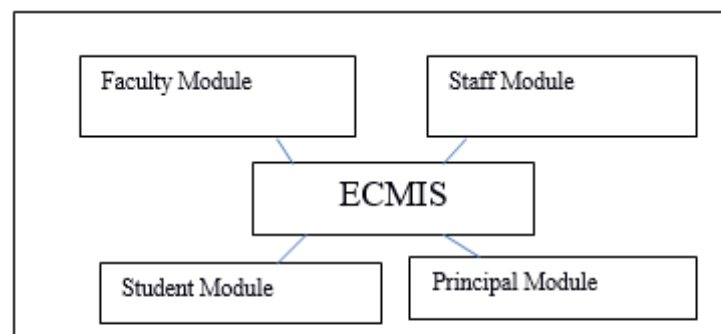

Fig.1: ECMIS Modules

Context flow diagram of E-College Management and Information system :

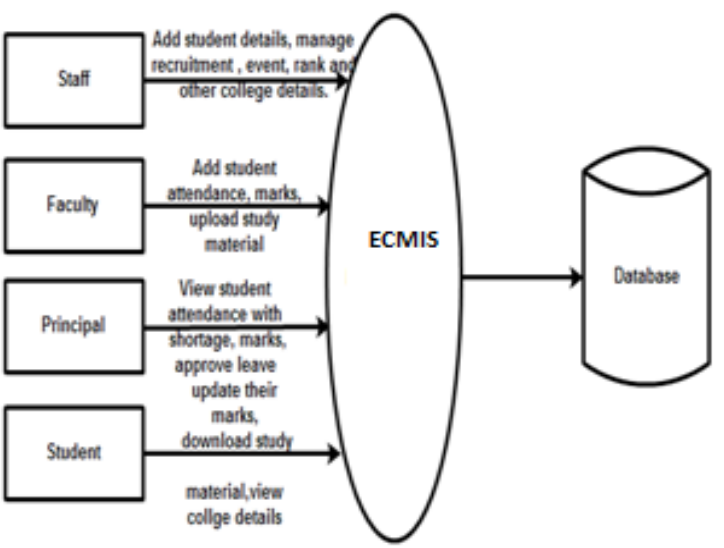

Fig.2: CFD of ECMIS

DFD- Data flow Diagram: It defines the actual flow of data throughout the system. It can also be used for the visualization of Data Processing [8] DFD shows the interaction between the system and outside entities. 


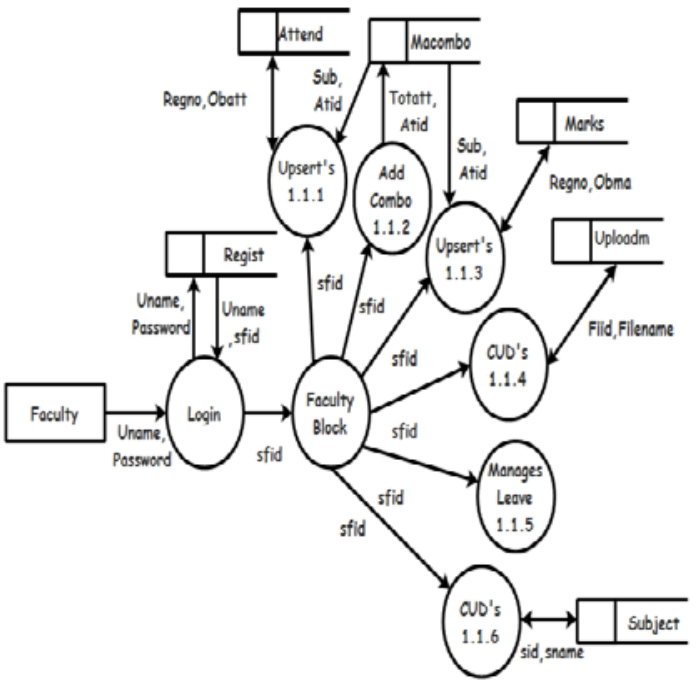

Fig.3: Level 1.1 Faculty Module

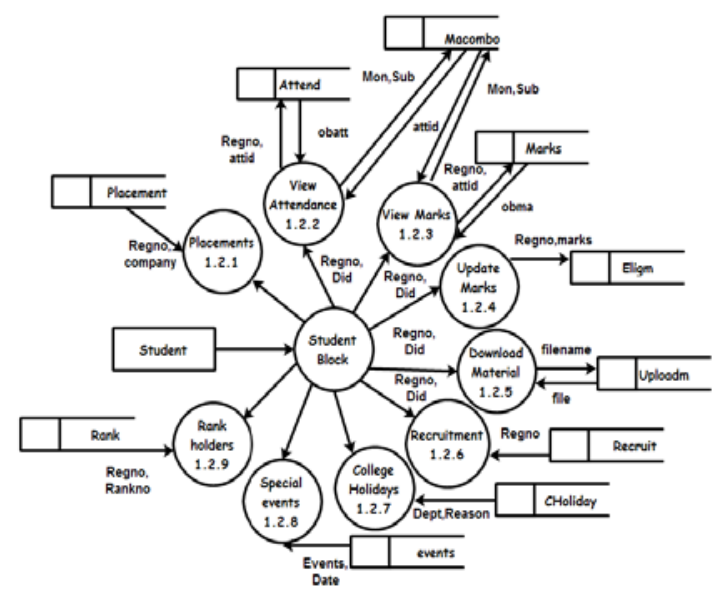

Fig.4: Level 1.2 Student

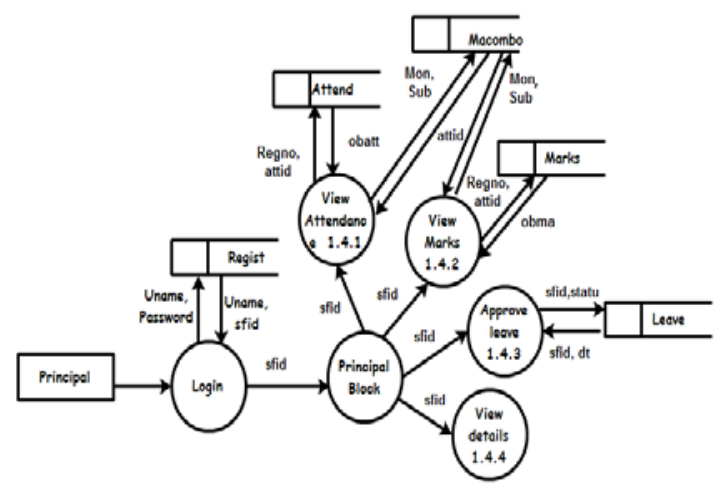

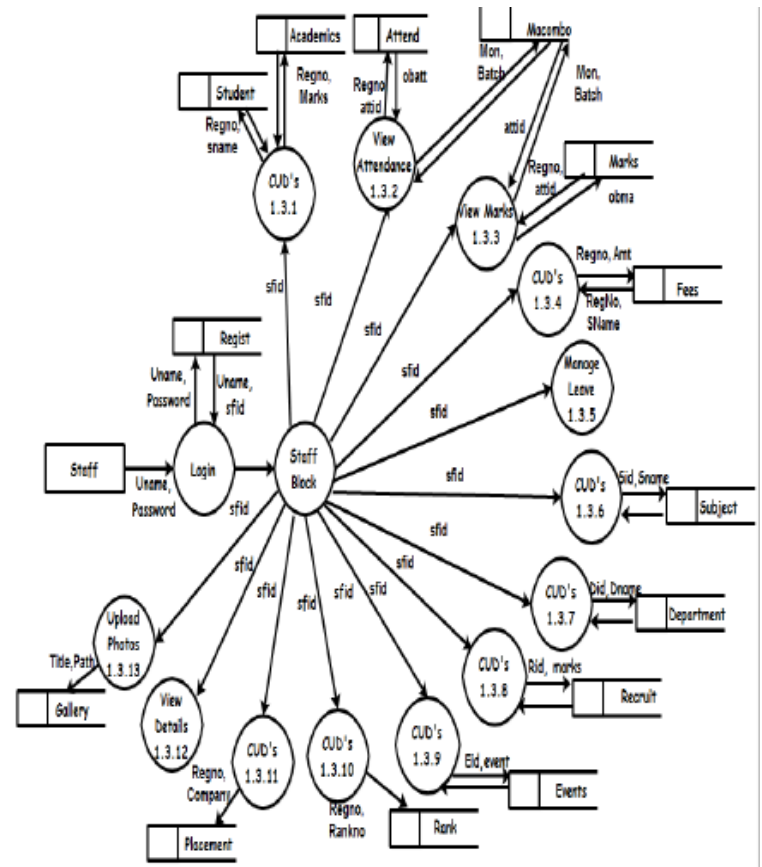

Fig.6: Level 1.3 Staff Module

$\underline{\text { Level 2.1 for 1.1.5 and 1.3.5 }}$

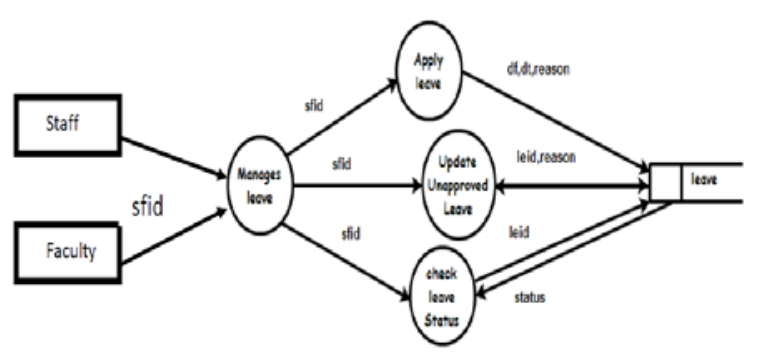

Fig.7: Staff and Faculty Leave

Level 2.2 for 1.3.12

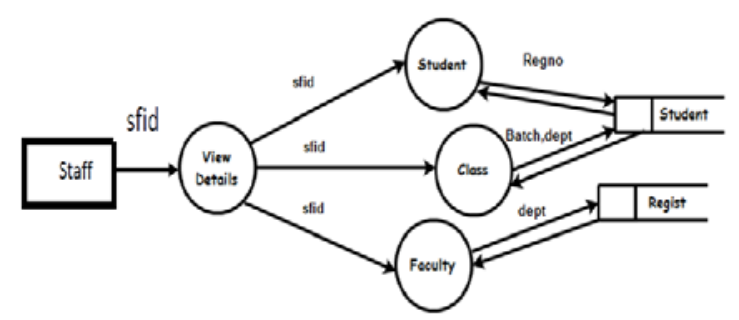

Fig.8: Detail Module

Fig.5: Level 1.4 Principal Module 


\section{MODULE DESCRIPTION :}

\subsection{Faculty Module}

Faculty perform the following functions:

Registration: Faculty are supposed to be registered before using the system. Each of the registrations will be approved by already registered Staff/Faculty. After registration Verification; Verified user will be permitted to login using username and password.

Enter/Edit Attendance: Faculty can enter student attendance, according to their teaching subjects which can be edited. They can even view the attendance shortage list subject-wise

Enter/Edit Marks: Faculty can enter student Marks according to their teaching subjects which can be edited.

Upload Study Material: Faculty can upload study materials which will be available to students they can even edit them or delete them.

Apply Leave: Faculty can apply for leave and even check their leave status. They can even take unauthorized leaves which will be highlighted while viewing current years leave details.

Edit Profile: Faculty can edit their profile.

\subsection{Staff Module:}

Staffs perform following functions:

Registration: Staffs are supposed to be registered before using the system. Each of the registrations will be approved by already registered Staff/Faculty. After registration Verification; Verified user will be permitted to login using username and password.

Admission: Staff is allowed to enter /view/ edit student Personal details as well as academic details.

View Marks and Attendance: They can view the student attendance as well as Marks. They can even view attendance shortage of respective classes.

Manage Fee details: They can manage student ID card Fee/Library card fee/Exam fee/Fine details.

Manage subject and department: They are supposed to manage and update subject and course details.

Manage other college details: They are supposed to manage and update college holiday, special events, Rank details, Placement Details and even manage the site Image gallery.

Apply Leave: Staff can apply for leave and even check their leave status. They can even take unauthorized leaves which will be highlighted while viewing current years leave details.

Manage query: They manage different reports and Queries based on vast options related to students, class, cast, course, staff / faculty.

Edit Profile: Staff can edit their profile.

\subsection{Student Module:}

Students perform following functions:

Attendance Status: Student can view their attendance status.

Internal Marks: Student can view their Internal Exam, Project marks

College Events: Students are updated regarding college events.

Download study Material: Students can download the uploaded study materials.

Update Aggregate marks: they can update their current aggregate score to check their eligibility in various recruitment opportunities.

View College details: They are even updated with various details like Rank, College Holidays Recruitment and Placement.

7.4 Principal module:

Principal performs following function:

Approve leave: Principal can approve leave by checking the current years leave details of Staff/Faculty.

View Details: Principal can view student as well as Staff/Faculty details.

Student Academic Details: Principal can view student's academic details.

\section{CONCLUSION :}

This application automates the work and provides efficiency and accuracy. Records are computerized, less time consuming, easy to maintain all the details, No or very few paper works, all details will be available at a click. The storage facilities will ease the work of all the users. By using Existing System accessing information from files is a difficult task and there is no quick and easy way to keep the records of students and staff. Lack of automation is also there in the Existing System.The aim of Our System is to reduce the workload and to save significant staff time. 
The silent features of the system are:

- User friendliness for data entry through structure query language, which allows the user to perform the operation with ease.

- The database has been successful in eliminating the various manual and the traditional procedure that was employed.

- Processing is done faster data security and input errors are maintained. Reports are generated as and when required based on the criteria given.

\section{REFERENCES :}

[1] Hashim, N. M. Z., \& Mohamed, S. N. K. S. (2013). Development of student information system. International Journal of Science and Research (IJSR), 2, 256-260.

[2] Patnaik, S., Kumari Singh, K., Ranjan, R., \& Kumari, N. (2016). College Management System. International Research Journal of Engineering and Technology (IRJET), 3(5), 659-661.

[3] Rajmane, S. S., Mathpati, S. R., \& Dawle, J. K. (2016). Digitalization of Management System for College and Student Information. Research Journal of Science and Technology, 8(4), 179-180.

[4] Bharamagoudar, S. R., Geeta, R. B., \& Totad, S. G. (2013). Web based student information management system. International Journal of Advanced Research in Computer and Communication Engineering, 2(6), 2342-2348.

[5] Narlawar, N., Hande, N., Phalake, M., Joshi, R., \& Padgilwar, N. (2014). College Management Module's Constructed by Advance Java in the ERP System. Current Trends in Technology and Science, 3(3),164-167.

[6] Yue, Z. G., \& Jin, Y. W. (2010, August). The development and design of the student management system based on the network environment. International Conference onMultimedia Communications (Mediacom), (pp. 5-8), IEEE.

[7] Yuvarani, R., Sangeetha, K., Sharmila, S.,
\&Ezhumalai, P. (2018). Department Automation System. International Journal of Engineering Science, 8(2), 17062-17064.

[8] Tang, Y. F., \& Zhang, Y. S. (2009, August). Design and implementation of college student information management system based on web Services.IT in Medicine \& Education, 2009.IEEE International Symposium on (Vol. 1, pp. 1044-1048), IEEE.

[9] Norasiah, M. A., \& Norhayati, A. (2003, January). Intelligent student information system. 4th National Conference onTelecommunication Technology, NCTT 2003, Proceedings. (pp. 212-215), IEEE. 